IBIMA Publishing

Journal of Eastern Europe Research in Business and Economics

http://www.ibimapublishing.com/journals/JEERBE/jeerbe.html

Vol. 2016 (2016), Article ID 602146, 10 pages

DOI: $10.5171 / 2016.602146$

Research Article

\title{
Adoption Of IFRSs In Russia: 22 Years Of Accounting Reforms
}

\author{
Natalia Generalova, Genrietta Soboleva and Natalia Sokolova
}

Saint-Petersburg State University, Saint-Petersburg, Russia

Correspondence should be addressed to: Natalia Generalova; n.v.generalova@spbu.ru

Received date: 2 March 2015; Accepted date: 13 June 2015; Published date: 6 September 2016

Copyright (C) 2016. Natalia Generalova, Genrietta Soboleva and Natalia Sokolova. Distributed under Creative Commons CC-BY 4.0

\begin{abstract}
The paper deals with review of Russian accounting reform, which took place during 19922014 years. This reform showed that Russia has not just copied IFRS but it has chosen the way of reasonable and prudent their application. The essence of this approach is following: convergence with IFRS and RAS (Russian accounting standards): the financial statements are drawn up in accordance with RAS which in turn are developed under IFRS; introducing a mandatory requirement of drawing up consolidated statement under IFRS, as well as its mandatory audit and publication: consolidated financial statements of public companies are formed under IFRS.This paper reviews real applications IFRS in Russia: de-jure and the defacto. It is drawn conclusion that influence of IFRS methodology affected to accounting and, as a consequence, on its analysis. We have concluded that the main changes in national standards consist in appearance of professional judgment and economic interpretation of economic life facts. The article also presents and analyzes challenges in the application of the concept of professional judgment in Russia. Particularly, dynamic study of methodology of accounting education in Russia in 2004-2015 shows that limitations in the application of IFRS in Russia related to the national peculiarities of application of professional judgment and specific approach in the interpretation of the facts of economic life.In the paper also shows influence of IFRS adoption in Russia on conceptual framework of financial reporting: assets, liabilities, capital, income, expenses, and others.
\end{abstract}

Keywords: IFRS, accounting reform, adoption of IFRS, convergence

\section{INTRODUCTION}

The economic crisis of the early twentyfirst century showed that financial reporting should serve the function of providing users with financial information, useful for management decisions. Otherwise, it is inefficient and, in some cases even destructive - benefits from its use does not cover its costs. Key information problems of financial reporting arise from the methodology of accounting: a low transparency due to incomplete requirements of the presentation and disclosure of information, a lack of comparability of financial statements prepared in accordance with national standards; not fully reflection of all economic life facts (transactions with financial instruments, contractual 
obligations); excessive optimism (accrual method requires the recognition of income while money has not received yet, the fair value accounting, etc.). The course of solving these and other problems was set by worldwide accounting community long time ago while Russia joined it only in the late 90s when they intended carrying out reforms in accounting.

\section{The Stages of Accounting Reform in Russia}

By the time the accounting reform started in the late 90s, Russia had inherited from the Soviet Union the economic relations established under the planned economy system. That period was marked by such distinctive features as the state regulation of accounting through issuing normative documents obligatory for application; the complete standardization and unification of accounting procedures and records; the unified system of accounting. Subsequently the main purpose of accounting was to ensure the security and the rational use of public property. In the book by Sokolov (2005) mentioned despite the obvious advantages of the Soviet accounting system, it failed to cope with the challenges posed by the new management conditions of the market economy.

The accounting and reporting reform in Russia has continued to the present day without being limited to convergence with IFRS. The change in regulation is viewed as a specific area of the reform. The essence of the reforms is a move from tight state control to the judicious combination of public and professional regulation. The new Law on Accounting is scheduled to be passed in 2013 [3].

Thus, in the course of over twenty years (from 1989 till 2013) that the accounting reform was conducted in Russia, it adhered to the policy of 'adjusting the national accounting and reporting system to the requirements of the market economy and IFRS' with due account for the specific circumstances and the analysis of the encountered problems. Instead of rushing headlong into applying IFRS Russia adopted the system of its 'well-balanced and gradual' implementation. Such an approach consists in maintaining the national system of accounting and reporting, which is based on IFRS, and requiring from public companies to draw up their consolidated financial statements directly in accordance with IFRS.

In a results of complex inspection «Implementation of the Accounting Reform Russian Federation Realization» (2004, $2006,2007)$ mentioned that the accounting reforms, which took place in the period between 1992 and 2010, showed that Russia has not just copied IFRS, but has chosen a most reasonable and prudent way of the international standards application. The following are the issues that demonstrate the essence of this approach:

- The integration of IFRS into RAS: financial statements are required to be drawn up in accordance with RAS, which in their turn are based on IFRS;

- The introduction of a mandatory requirement for drawing up consolidated statements along the IFRS lines, as well as their mandatory audit and publication: the public companies' consolidated financial statements are formed under IFRS.

Firstly, this approach makes accounting and reporting regulation possible at the state level (financial reports are formed under RAS). Secondly, it will contribute to increasing the attractiveness of the Russian market for foreign investors due to the use of IFRS in the' consolidated financial statements of public companies.

Clearly, the international standards have strong influence over the reporting of accounting information by Russian companies. They have gained such influence due to the effects produced on the national accounting standards and also due to the fact that a large number of Russian companies currently prepare their reporting in compliance with IFRS. The adoption of the Federal Law No.208 On Consolidated Financial Statements dated 27 July 2010 for the preparation of financial reports in accordance with IFRS will enable IFRS reporting in Russia to 
achieve a legal status. This is expected to improve the reporting quality due to a higher degree of responsibility.

\section{Realities}

To answer the question how international standards are applied in Russia now it is vital to analyze the application of international accounting standards in the country.

Implementation of IFRS cannot exist only due to application of these standards on a voluntary basis. Investors and other users of financial statements always need the legal protection of their interests in getting fair financial information. Therefore legal duty of providing should be obligatory. The introduction of IFRS in Russian legal system can be divided into the following three parts.

1) Direct application: financial reporting of credit agencies drawn up on basis of IFRS.

2) Direct application: consolidated reporting of public companies drawn up on IFRS basis recognized for use in Russia.

Federal Law No.208 "On the consolidated financial statements dated 27 July 2010 was the first one that introduced the application of IFRS in Russia at the legislative level. According to this document; "consolidated financial reporting is to be prepared in accordance with IFRS" (p.1, art.3). The importance is that "in Russia IFRS can be applied in order established in the requirements of the legislation set up by the Government of the Russian Federation and Central Bank" (p.2, Art. 3). Scope of the Law is credit, insurance and other organizations whose shares and bonds are traded on stock markets. However, the date when Russian companies are starting to prepare consolidated financial statements on basis of IFRS has not been fixed yet. The reason is following. The Law states that "Organizations starts draw up, represent and publish consolidated financial statements in the year following the year when IFRS are recognized for use in the
Russian Federation ..." (p. 1, art 8). Nevertheless, the application of IFRS in Russia has not been still implemented. However, the website of the Ministry of Finance has published a Draft Resolution of Russian Government "On Approval of the Conditions of IFRS application and Interpretations of IFRS in Russia". According to the draft the recognition of the IFRS documents means the decision making process of introducing each document being part of IFRS into force on the territory of the Russian Federation. The transition to IFRS is planned in 2015.

3) Indirect application: financial reporting drawn up in accordance with the RAS but on the basis of IFRS.

Financial reporting of Russian companies is drawn up in accordance with national standards while they are developed on the basis of IFRS. This approach of accounting and reporting regulation in Russia is recorded on the state level and implemented consistently throughout the whole period of the reform. Thereby the reporting drawn up on basis of RAS is meet IFRS.

In reality many Russian companies had made a transition to IFRS much earlier than it was announced in legal acts. Voluntary reporting by Russian companies on the basis of IFRS resulted from the fact that totally new market economy gave companies a chance to raise a capital through market mechanisms and mainly from international capital markets. Since 2005 the major Russian stock exchanges MICEX and RTS made companies whose shares and bonds of class "A" first and second levels are listed to draw up a reporting on basis of IFRS. 'The availability of annual financial (accounting) statements in accordance with International Financial Reporting Standards (IFRS) and (or) Generally Accepted Accounting Principles in U.S. (US GAAP) and its disclose in Russian (Rules of Listing, Admission to placement and circulation of securities in the MICEX).

In recent years the number of Russian companies that draw up their reporting on 
basis of IFRS has been steadily increasing. Thereby it is obvious now that international standards have a significant influence on the forming reporting information in Russian companies. It is being done successfully through the effects on national accounting standards and also due to the fact that some Russian companies form already a direct reporting according to IFRS, including credit institutions which are obligated by Central Bank of Russia.

\section{Challenges and Consequence}

According Pyatov (2009) adoption of IFRS in Russia has led to a revision of accounting methodology. Changes in IFRS adopting and in RAS, caused by the use of IFRS has significantly resulted in financial performance of organization. Every fact of economic life results in the reporting and, accordingly, influences on the decisions made by interested users based on this information. Therefore, it is the user and his information needs that is the main reason for differences in reporting according to RAS and IFRS. A key user of financial reporting prepared according to international standards is an investor. The purpose of reporting under Framework for the Preparation and Presentation of Financial Statements (further Framework) is not only to supply information but to supply useful information which is valuable for making economic decisions. Russian system of accounting and reporting inherited from the Soviet Union was always state-oriented. Moreover, despite all attempts to change the situation, in practice it is usually the state or tax authorities that is a real user of reporting. Thereby, information is rarely investorsoriented as mentioned in the book by Enthoven, Sokolov, Kovalev, Bychkova, Smirnova, Semenova (2006).

According to Ball (2006), the concept of "presenting useful information for investors" results in IFRS basis on economic doctrine about the qualified facts of economic life. Thereby there is the priority of substance over form, present value, impairment, fair value, consolidation and other ideas, which sometimes have nothing in common with legal component of transactions. What is meant is the theory of multilayer fact of economic life, according to which the fact of economic life is made up of several layers. One classification of facts layers is their division into economic and legal ones. According to principle of complementarity the more accurate one indicator (economic nature of the economic situation), the less accurate the other is (legal aspect of a transaction) as mentioned in a research by Roberts, Weetman and Gordon (2009).While IFRS pay more attention to economic layer, legal one stays in the background. Russia being a country with a continental model of accounting has always a legal vision. Thereby, the transition to IFRS in Russia was influenced by following facts: in addition to changes in the reporting user there was a shift in interpretations of economic life facts (now the economic layer is first-priority according to Jorisson, Lybaert and Van de Poel (2006)).

In next paragraphs it is disclosed how the transition to IFRS in Russia has resulted in the concept of Russian financial reporting.

Accrual method: This method is an underlying assumption in the IFRS as it meets the interests of owners recognizing revenue as soon as possible to and thus pays out investors their dividends. However it is important to understand that this approach can be dangerous in mass using because it misrepresents income data in terms of providing real cash flows. And as for cash method it allows to evaluate the facts of economic life in relation to cash flow.

Substance over Form: This principle exist as in RAS (par.7 RAS 1/2008 establishes the requirement of substance over form) as in IFRS (par.35 Framework). However, sometimes Russian normative documents contain standards which allow ignoring the rule according to research by Chen (2009).

Conservatism: Conservatism (prudence) is one of the main principles of IFRS but it and should not be regarded as the highest good. As unfortunate experience of failed major U.S. companies have recently shown, 
conservatism, which requires showing assets and revenues at least, and commitment at highest possible ratings, does not always work and give expected result. Reflecting in the reporting undervalued assets and overvalued liabilities an accountant creates hidden reserves and thus misrepresents the information for its users. In a research study by Hellman (2008) and Nobes (2010) mentioned that subsequently, during liquidation of hidden reserves undue profit appears which leads to an overstatement of profitability. The same opinion is shared by classics of accounting Hendrickson and van Breda: "... Conservatism denies credentials comparability ... deliberate underestimation of credentials can lead to unfortunate decisions as well as are deliberate overestimation". Professor of Economics and Director of the Institute of Auditors of Munich University, Professor Emeritus of Vienna University Jorge Betge also criticizes the principle of conservatism of IFRS arguing, "having a lot of alternative methods of evaluation principle of conservatism requires choosing the most pessimistic as the most likely".

Assets: According to Framework asset is a resource controlled by the entity as a result of past events and from which future economic benefits are expected to flow to the entity. What are important in the definition of assets are "control" and "economic benefits". Control assumes the transition of risks and rewards, while asset ownership is not an obligatory condition of object recognition as an asset. One example of differences in the definition of assets under IFRS and RAS is a reflection of finance lease. According to IAS 17 Leases an object of finance lease is recorded on balance of a lessee in spite of the fact whether passing of property was or not. According to RAS similar objects can be reflected on off-balance accounts, so that they are not recognized by the company. An example of differences in the definition of "economic benefits" may be the recognition of social facilities. Usually one question arises whether it is possible to reflect them as fixed assets, as it is not always easily to show the probability of economic benefits of such assets. For example, some companies reporting on the basis of IFRS have already stopped recognizing such objects of social sphere as assets.

Formation of assets according to ownership meets goals of estimating creditworthiness of organization, since only owns property can be a security for the obligations. At the same time, the estimation of profitability made on the basis of this information will be overstated, since the calculation in this case does not take in account the assets that do bring profit, but are not their own and therefore find no reflection in the balance. From this point of view, more reasonable approach is represented in IFRS as according to IFRS assets are resources which are controlled by the company and profit-generating as mentioned in a book by Alexander, Britton, Jorissen (2007).

Liabilities: In IFRS (Framework), definition of liability is following: "a liability is a present obligation of the entity arising from past events, the settlement of which is expected to result in an outflow from the entity of resources embodying economic benefits." It seems that the liability under IFRS and RAS should be the same, but it is not true. As the boundaries as the estimation of liabilities differ in two systems. Considering the boundaries of the liabilities it can be noticed that there are some liabilities that are established by RAS but do not meet the criteria of recognition under IFRS and vice versa. Dominance of the economic nature of the liabilities in IFRS and legal one in RAS determines the differences in their measurement. In Russia dominates measurement of liabilities at historical cost while in international practice there are several possible measurement including measurement of present value. This fact usually leads to an overestimation of liquidity and financial stability of a company in statements.

Equity. Definition of this element of reporting the same on RAS and IAS: "equity is the residual interest in the assets of the entity after deducting all its liabilities» (Framework). Difference in equity under RAS and IFRS is determined by the 
difference in measurement and composition of assets and liabilities. However, there are also differences caused by distinction in the structure of equity itself. For example, preference share, which is redeemable are considered as equity (equity instrument) by RAS and as liability (debt instrument) by IFRS.

Income and Expenses: IFRS define income as "increases in economic benefits during the accounting period in the form of inflows or enhancements of assets or decreases of liabilities that result in increases in equity, other than those relating to contributions from equity participants» (Framework). The company's income includes revenues (revenues from ordinary activities) and other income (gain). Expenses are a mirror of income: "decreases in economic benefits during the accounting period in the form of outflows or depletions of assets or incurrence of liabilities that result in decreases in equity, other than those relating to distributions to equity participants". Expenses include expenses incurred during the ordinary activity of the company and losses. Differences in the recognition of these elements of reporting are following. Discrepancy between the measurement (IFRS revenues are recognized at fair value of expected or received compensation, including the present value in case of long delay of payment); discrepancy between the times of recognition of income (expenses); different boundaries of incomes and expenses.

Exchange differences on foreign operations leads to the fact that a comparison of revenues and expenses recognized under IFRS leads to the formation of a broader index than just net profit for the period, because of taking into account changes in equity. A dramatically new reporting indicator - comprehensive income appeared in IFRS financial statements from 1 January 2009 (in RAS reporting from 1 January 2011). It is obvious that differences in the recognition of income and expenses result in analytical indexes of company's profitability. Profitability determined on the basis of net profit reflects the effectiveness of company's management and does not take into account external factors while profitability measured on the basis of comprehensive income reflects the effectiveness of the organization as a business entity as mentioned in a research by Barth (2006).

Measurement of the elements of financial reporting: This component of the conceptual framework of financial reporting is a central one as quantitative changes in elements not only determine their recognition but also significantly result in the understanding of company's financial position according to Schipper and Trombetta (2010). For example, measurement of assets and liabilities affects income (expense) which in turn determines the value of equity. The main differences are indicated below.

Time value of money (present value): Drawing up the reporting in accordance with IFRS time value of money should be considered. Thus, any payment delay should be taken onto account as a either company is funded by someone or someone funds it. Payments must be divided into actual cost for goods or services and interest expenses. However, RAS do not apply present value. Present value is used in all situations where there is a gap between payment and acquisition such as when calculating the cost of fixed assets, intangible assets, investment property and other assets. Present value primarily affects the analytical indexes of creditworthiness allowing matching timecomparable assets and obligations, while estimation using historical cost cannot afford it.

Fair value: In comparison with RAS, international standards widely apply fair value. In Framework Fair value is the amount for which an asset could be exchanged, or a liability settled, between knowledgeable, willing parties in an arm's length transaction. Fair value is probably a way of determining the need of measurement. Fair value is becoming more and more popular nowadays since almost all "new" standards, as well as new editions of "old" ones point out the application of fair value. In addition to the obvious 
advantages of this approach (updating of financial information) there are also significant drawbacks connected with reliability of the provided information. For instance, the definition of fair value is largely based on subjective judgments of preparers and appraisers and some cases just do not exist. Foreign appraisers have been always announcing that in CIS fair value did not exist at all for a long period of time because only active market, where deals are made by constantly, proves the presence of fair value.

Impairment: According to IAS 36 «Impairment of Assets» an asset is described as impaired and the IAS 36 requires the recording of an impairment loss when its carrying amount exceeds the recoverable amount (amount to be recovered through use, or sale). Requirements for reflection impairment of assets are absent in RAS. Various methods of measurement of assets correspond with different targets of users of accounting information. For example, according to Generalova and Sokolova (2014) historical cost, mainly used in Russian practice, correspond with the objectives of determining profitability, but with the objectives of determining creditworthiness.

Professional judgment: Identification of the fact of economic life includes classification, measurement, timing and method of recognition, disclosure in financial reporting. Applying the concept of professional judgments involves the understanding of following key issues. Professional opinion is objective because it is based on an analysis of historical fact of economic life; professional opinion is subjective, since it is an opinion based on knowledge, skills and experience of a particular specialist; the "criterion of correctness" of professional judgments is the fair financial reporting; "guarantee of correctness" of professional judgments is audit of financial statement; professional judgment is not static as new information appears all the time; professional judgment needs to be regulated at the regulatory level (public or professional) as the boundary between the judgments and hiding, and even fraud is blurred as mentioned in research by Generalova (2005) and Sokolova (2012).

Drawing up statement in accordance with IFRS an accountant inevitably makes subjective opinion qualifying facts of economic life: determining the useful life, selecting the depreciation method, recognition of liabilities, determining of impairment loss, choice of discount rate and in many other cases.

Not only the formation of the necessary legislative framework has a significant impact on how professional judgment is applied in accounting system and what problems arise in this area. Significant impact on the ability to produce professional judgment have the representatives of the profession themselves - their mentality, traditions and customs of the existing business environment.

Numerous studies of scientists from various countries testify to this. In a research study by Doupnik and Riccio (2006) mentioned that the human factor in conditions of uncertainty, existing in international standards, has a significant effect on the final decision when making judgment. Moreover, there are national peculiarities of professionals relating to formation of their opinion. So the German Accounting tend to show significantly higher level of conservatism than their American counterparts, and Brazilian experts are inclined to pay much more attention to the disclosure of information under conditions of uncertainty according to Flamholtz and Cook (1978). Some studies suggest that similar mental features lead to differences in income and expense recognition as mentioned in research by Chand, Cummings, Patel (2012).

The formation of the national mentality and ability of accountants to work successfully in cases of uncertainty is also affected by education system. The research by Parmond Chand and Lorne Cummings shows that there are significant differences between students studying accounting profession in China and in Australia. As noted in research by Salter and Schulz 
(2005), the continuing education of Chinese students in Australia smoothes, though does not eliminate the differences. This study can be considered as a strong evidence of influence of the learning process on the formation of the psychological characteristics of Accountants and their ability to competently make professional decisions in the application of standards.

Russian professional environment problem was that it had inherited an education system that had significant formalist traditions. A feature of the system approach was that the goals and objectives of accounting were not a priority of the educational process. Information value of financial statements has not been considered in the education system. Unified system of education implies learning primarily technical skills and the ability to closely follow the existing regulations.

Changes in the economic system and the abandonment of the planned economy had an impact on all aspects of life, including the education system. In learning processes have been introduced concepts of information relevance of financial statements. A huge impact on the introduction of innovations has the representatives of international audit firms. However, the effort to overcome the existing problems has failed. Still considerable attention in the training is given to the study of instructions and regulations. The basis of the methodology is the study of procedures but not principles of reflecting information. Its links with the practice of the learning process are weak. This can be proved by the studies in Russian universities.

In 2003, in the Russian Federation was conducted a study on the situation at Russian education in the field of accounting. The study involved 11 largest universities in different regions of Russia, including Saint Petersburg and Moscow. The study had two objectives: to identify whether graduates have sufficient skills and to determine the willingness to develop independent judgment. The results showed a fairly high level of students' professional skills and techniques. At the same time no more than $10 \%$ of the audience appeared to be ready to solve professional tasks that required them to form and claim their professional judgments. A significant part of the subjects in general refused to solve such problems.

Unfortunately, this trend has not changed so far. A study conducted in 2014 in a number of economic institutions, showed that students have a good knowledge of sustainable relating directly to the technical and technological sides of the organization and record keeping. However, most of them are still not ready to form their own professional judgment. Especially poor results were obtained in the case where the proposed objectives are beyond normal conventional operations. It should be noted that the positive changes still occur. So students are much more responsive to the decision of the contingency situations that are reviewed and analyzed in detail in the international standards of financial accounting. The proportion of students who clearly understand the meaning and consequences of information application of certain accounting methods and the need for a statement of their professional judgment has increased. A significant part of the students is aware of the mission of the accounting employee in reporting users the most reliable information about the recorded facts of economic life.

\section{Conclusion}

To sum it up, under IFRS the reliability of accounting information and the implementation of the role of financial reporting in the economic life of society as a reliable basis for making management decisions is based on professional judgments and economic treatment of businesses economic life facts. The whole ideology of international standards (time value of money, fair value, etc.) meets it. Such approach would provide a 'different reliability', rather than the approach based on the legal interpretation of economic life facts as mentioned in a research by Soboleva (2005). Reliability under IFRS - is 'one of reliabilities' of financial reporting, based on the Anglo-American model with 
its inherent attributes: professional judgments, the economic approach, etc. In comparison with national accounting standards reflection of economic life facts under IFRS can generate even greater variability in financial statement. The usage of accounting information formed in accordance with IFRS (or RAS is based on IFRS) should be when there is the understanding of how this information was formed.

In addition, we should understand that the criticism would always exist, because even assumption about what is better - national accounting rules or IFRS - is wrong. It has been shown that the use of Russian accounting rules or IFRS in different situations can show the user different indicators of financial position (creditworthiness, financial stability and profitability) of an organization.

\section{References}

1. Alexander D., Britton A., \& Jorissen A. (2007). International Financial Reporting and Analysis, 3rd ed., Thomson.

2. Ball R. (2006), International Financial Reporting Standards (IFRS): pros and cons for investors, Accounting and Business Research, International Accounting Forum.

3. Barth M. (2006), 'Including Estimates of the Future in Today's Financial Statements', Accounting Horizons, 20 (3), 271-285.

4. Chand P., Cummings L., Patel C. (2012). 'The effect of accounting education and National culture on accounting judgments', European accounting review, 21 (1), 153 182.

5. Chen Y. (2009), 'Use the Substanceover-Form Convention to Regulate the Related Transaction', International Journal of Business and Management, 4 (3), 156158.

6. Doupnik T.S., and Riccio E.L. (2006), 'The influence of conservatism and secrecy on the interpretation of verbal probability expressions in the Anglo and Latin cultural areas', The International Journal of Accounting, 41, 237-261.
7. Enthoven J.H., Sokolov Y.V., Kovalev V.V., Bychkova S.M., Smirnova I.A., Semenova M.V. (2006), Accounting, Auditing and Taxation in the Russian Federation [An Updated], The Center for International Accounting Development, The University of Texas at Dallas.

8. Flamholtz E. and Cook E. (1978). 'Connotative meaning and its role in accounting change: a field study', Accounting, Organizations and Society, 3(2), 115-139

9. Generalova N., Sokolova N. (2014), 'Challenges in goodwill impairment', International Accounting, 26, 2-14

10.Generalova N. (2005),' Professional judgement and financial reporting' , Accounting (in Russian), 13, 54-61.

11.Generalova N, Popova E. (2014), 'The problem of localization of economic science by the example of study of the scientific literature on accounting for goodwill in Russia and abroad' International Conference on Accounting, Auditing, and Taxation (ICAAT 2014), DEStech Publications, Inc. Lancaster, USA, 53-60

12.Jorisson A., Lybaert N. and Van de Poel K. (2006), 'Lobbying towards a global standard setter - do national characteristics matter? An analysis of the comment letters written to the IASB', International Accounting Standards, Regulations, and Financial Reporting. Elsevier Ltd., 1-41.

13.Hellman N. (2008) 'Accounting Conservatism under IFRS', Accounting in Europe, 5( 2), 71-100.

14.Nobes C. (2010), 'On Researching into the Use of IFRS by Private Entities in Europe', Accounting in Europe, 7 (2), 213226.

15.Pjatov M. L. (2009), Accounting for to make the manager decisions, Publishing House "1C Publishing", Moscow. 
16.Results of complex inspection of «Implementation of the Accounting Reform Russian Federation Realization» (2004), Moscow.

17.Results of complex inspection of «Implementation of the Accounting Reform Russian Federation Realization», (2006), Moscow.

18. Results of complex inspection of "Implementation of the Accounting Reform Russian Federation Realization»,(2007), Moscow.

19.Roberts C., Weetman P. and Gordon P. (2009) , International Financial Accounting: A Comparative Approach, Pearson.
20.Schipper K., Trombetta M. (2010), 'Measurement Issues in Financial Reporting', European Accounting Review, 19 (3), 143-154.

21.Salter S.B., and Schulz A. (2005). 'Examining the role of culture and acculturation in information sharing'. Advances in Accounting Behavioural Research. 8, 189-212.

22.Soboleva G.V (2005), 'Problems of training specialists in the field of accounting', Finance and Business, 3, 94-98.

23.Sokolov Y.V. (2005), 'Destiny of the IFRS in Russia', Finance and Business, 1, 69-83.

24.Sokolova N.A. (2012), 'Creative accounting: causes and consequences' , Finance and Business, 3, 94-98. 